Int. J. Morphol.,

35(2):556-563, 2017.

\title{
Early and Late Outcomes of Surgery of Non-Complicated Liver Hydatid
}

\author{
Resultados Precoces y Tardíos de la Cirugía de la Hidatidosis Hepática no Complicada
}

Carlos Manterola ${ }^{1}$; Tamara Otzen² \& MINCIR group.

MANTEROLA, C.; OTZEN, T. \& MINCIR group. Early and late outcomes of surgery of non-complicated liver hydatid cysts. Int. J. Morphol., 35(2):556-563, 2017.

SUMMARY: Hepatic echinococcosis (HE) is a prevalent health problem, and there is limited published information regarding HE surgery. On the other hand, postoperative morbidity (POM) has not varied significantly. The aim of this study was to describe early and late outcomes in terms of POM of a series of patients with non-complicated liver hydatid cysts (NLHC) treated surgically. Prospective cohort. We included patients undergoing surgery for NLHC in the Hospital Regional and Clínica in Temuco, between 2000 and 2015. The main outcome variable was the development of early and late POM. Other variables of interest were hospital stay, mortality and recurrence. Surgical techniques used were total or subtotal pericystectomy and liver resection. Percentages, measures of central tendency and dispersion, and incidence were calculated. We studied 136 patients with a median age of 41 years and $60.3 \%$ female The median ultrasound diameter of the cysts was $15.0 \mathrm{~cm}$. The median surgical time was 95 minutes. The incidence of POM was $9.6 \%, 92.3 \%$ of whose cases were Grade I or II Dindo \& Clavien. The aetiology was $5.9 \%$ and $3.7 \%$ medical complications of surgical complications. There was no mortality and with a median follow up of 115 months, recurrence was observed in one patient, representing an incidence of $0.7 \%$. POM was determined in a cohort of patients with NLHC throughout an extended follow-up period, and the incidence and gravity of POM is smaller and of lower gravity than those previously published.

KEY WORDS: "Echinococcosis, Hepatic"[Mesh], Hepatic Hydatid Cyst, "Echinococcosis, Hepatic/surgery"[Mesh], "Treatment Outcome"[Mesh], "Postoperative Complications"'[Mesh].

\section{INTRODUCTION}

Hepatic echinococcosis (HE) is a common disease and a serious health problem in some geographical areas of Chile, one of which is La Araucanía Region (Martínez, 2011), where approximately 60 new cases per year are surgically treated. The absence of standard surgical treatment represents a main problem (Dziri et al., 2004). It is clear however, that surgery remains the principal treatment for $\mathrm{HE}$, should preserve liver function, have a low morbidity and mortality rate, and for it to be therapeutic, all living parasites must be removed and no viable daughter cysts (Fig. 1) or protoscolices left either in the residual cavity or anywhere else in the host.

However, despite this being a prevalent health problem, the information regarding HE surgery is not as extensively published as in other areas of surgery. Controversy persists regarding morbidity of HE surgery, because the behavior of this variable over time has not varied in a very relevant way, with heterogeneous reports independent of the place of production of the data. For example, in national articles of the 1990s, data of postoperative morbidity (POM) were reported from $49.0 \%$ to $68.5 \%$ (Sapunar et al., 1989; Hermosilla et al., 1991; Pinto, 1991; Apablaza et al., 1992; Camacho et al., 1996). Similar numbers were reported in foreign articles, with figures ranging from $34.7 \%$ to $62.5 \%$ (González et al., 1999; Sarotto et al., 1999; Correa et al., 2000). After 2000, the reality did not improve substantially, as POM numbers were published from $21.3 \%$ to $53.8 \%$ (Yorganci et al., 2002; Nari et al., 2003; Atmatzidis et al., 2005; Daradkeh et al.,

\footnotetext{
${ }^{1}$ Department of Surgery and Center of Excellence in Morphological and Surgical Studies (CEMyQ), Universidad de La Frontera, Temuco, Chile.

${ }^{2}$ Universidad de Tarapacá, Arica, Chile.

Partially financed by project DID-UFRO DI16-0119.
} 
2007; Gourgiotis et al., 2007; Agayev \& Agayev, 2008), a situation that could be explained by the heterogeneity of the populations analyzed in the different studies, which usually include patients with complicated and uncomplicated HE.

On the other hand, speaking POM is complex because of the multiplicity of variables that influence it, and because of the diversity in the severity of the complications and the implications of this variable in the prognosis of each patient.

Based on the above, Dindo \& Clavien designed and validated a classification based on the severity of the POM, allowing having an instrument that homogenizes the POM data (Dindo et al., 2004; Clavien et al., 2009).

The aim of this study was to describe the early and late outcomes of a series of patients with uncomplicated liver hydatid cysts (NLHC) treated surgically.

This manuscript was written according to the guidelines of the MInCir initiative for the reporting of outcomes of descriptive observational studies (Manterola \& Otzen, 2017a).

\section{MATERIAL AND METHOD}

Design: Concurrent cohort study, without comparison group.

Setting: The study was conducted in the Surgical Services of the Hospital Regional and the Clínica Mayor in Temuco, Chile between January 2000 and December 2015 (16 years).

Participants: Patients operated on for NLHC by the first author (CM), in the centers aforementioned during the study period were included. Patients treated laparoscopically, with concomitant hydatidosis in another location, previously operated for liver hydatidosis, and with some evolutionary complications of the disease (Manterola \& Urrutia, 2015a): liver abscess of hydatid origin (Manterola et al., 2003a; ; Manterola et al., 2009a; Manterola \& Urrutia, 2015b), cholangiohidatidosis (Manterola et al., 2001; Manterola \& Otzen, 2017b), thoracic involvement (Manterola et al., 2009b; Manterola \& Otzen, 2017c), hydatid peritonitis (Manterola et al., 2003b), anaphylaxis, and fistulization of the cyst to some structure of the digestive tract were excluded.

Study protocol: All patients were studied with general laboratory tests, immunodiagnostic and imaging (ultrasonography or CT scan (Fig. 2)).

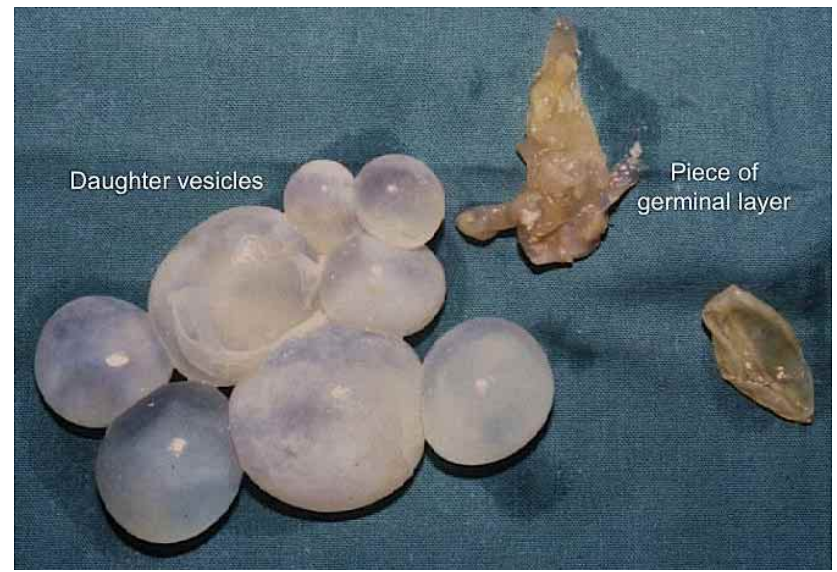

Fig. 1. Piece of germinal layer and daughter vesicles obtained from an NLHC.

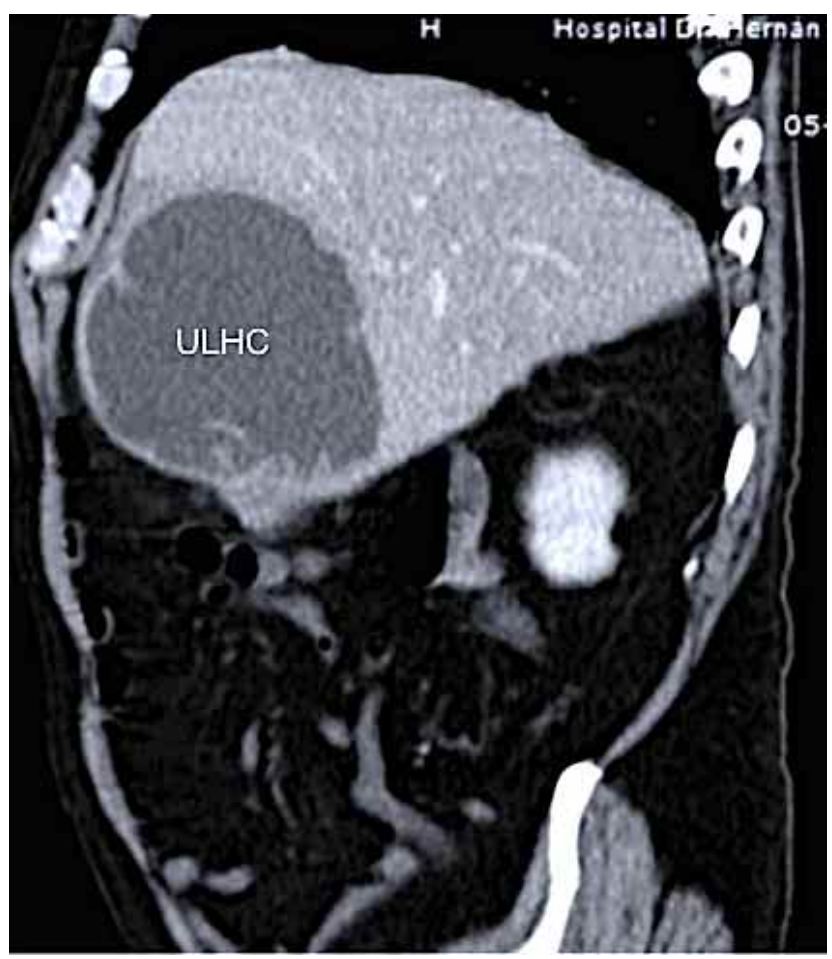

Fig. 2. CT Scan in which a NLHC compromises segments V and VI is observed.

Sampling: Non-probabilistic sample of consecutive cases.

Variables: Outcome variables were: "development of POM", dichotomously (yes/no, early/late and medical or surgical treatment), and applying the Dindo \& Clavien proposal (Table I) (Dindo et al.; Clavien et al.), measured at least 12 months after surgery. Hospital stay, need for reoperation, mortality and recurrence.

Follow-up: After hospital discharge patients were followed up at months 1, 6, 12, 24, 36, 48, 60 and thereafter once a 
Table I. Dindo \& Clavien Proposal.

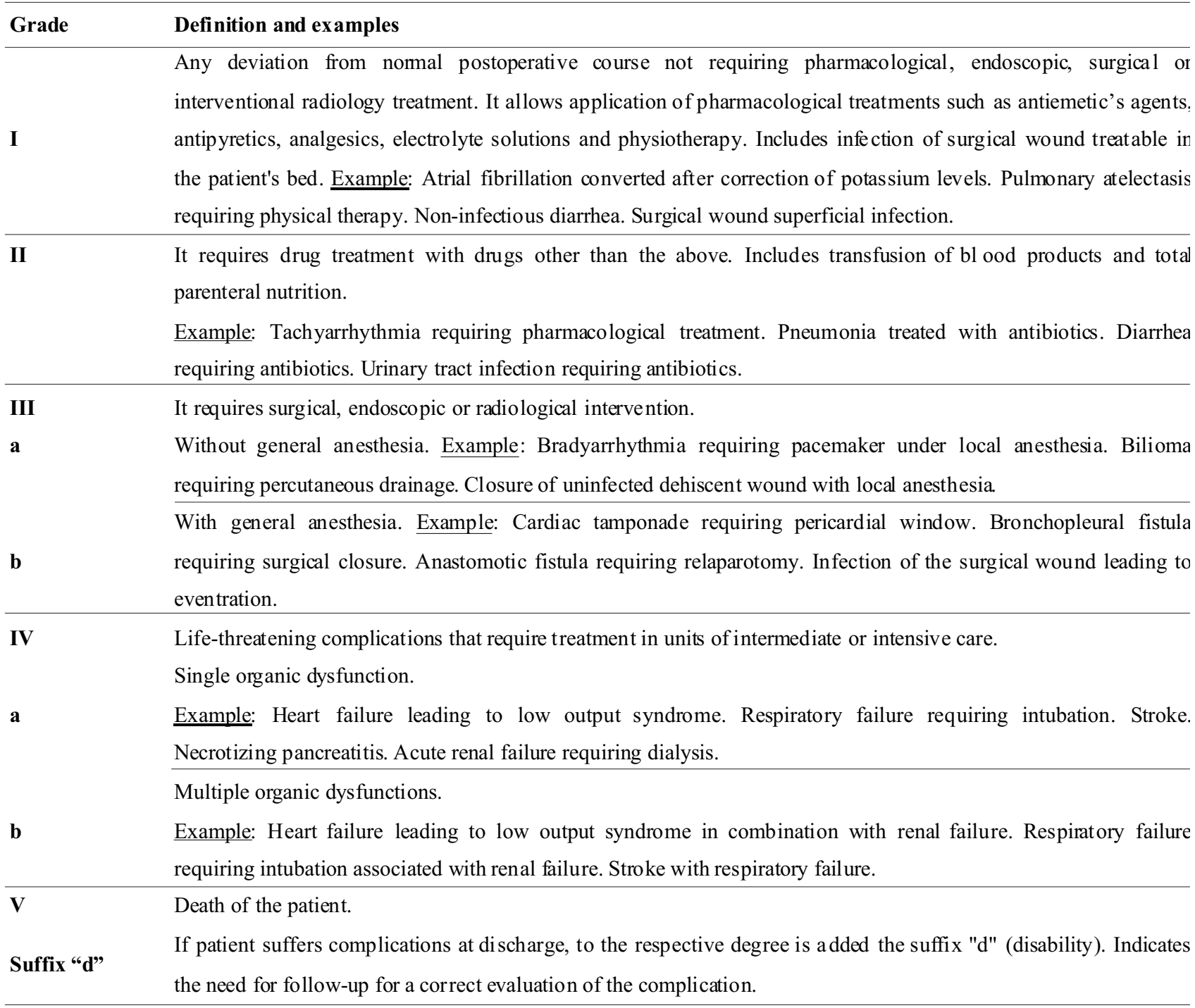

Note: Adaptation of original text.

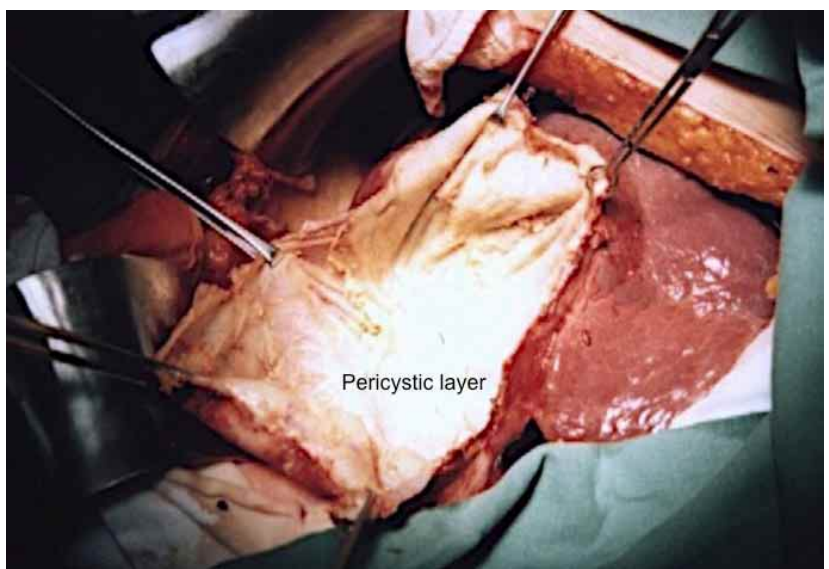

Fig. 3. NLHC $20 \mathrm{~cm}$ larger diameter, which compromises VI and VII segments. A subtotal pericystectomy is being performed, appreciating the entire pericystic layer.

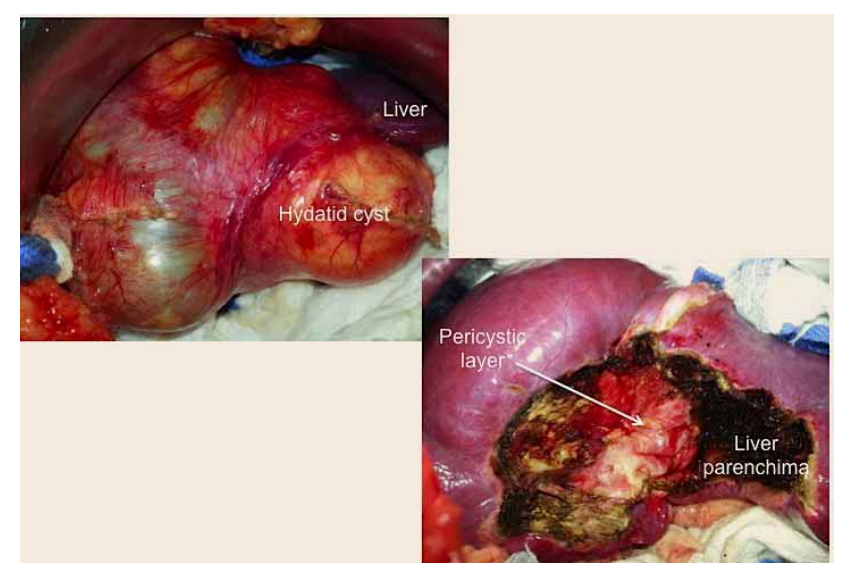

Fig. 4. NLHC $25 \mathrm{~cm}$ larger diameter, which compromises IVb, V and III segments. A subtotal pericystectomy was performed, leaving a pericyst plaque in the center of the bloody area. 
year with clinical monitoring, lab tests, immunodiagnostics with ELISA-IgG y ELISA-IgE (Manterola et al., 2007), abdominal ultrasonography and thorax x-ray.

Biases: At the time of the recruitment as well as at the time of clinical check-ups, biases were reduced with a complete follow-up of the patients comprising this series. Furthermore, data collection was masked.

Study size: Since it is an observational and descriptive study, no sample size was estimated.

Treatment: All patients underwent emergency surgery with prior antibiotic prophylaxis. There was no standard treatment, since the surgical procedures used were applied according to the intraoperative findings. According to these, total or subtotal percystectomy (Figs. 3 and 4 ) and hepatic resection were performed.

\section{Definitions:}

1. NLHC was defined as exclusive hepatic hydatid disease without evolutionary complications. Independent of the number of cysts, the diameter of the main lesion, the existence of biliary communications and cyst relationship with perihepatic vascular structures (Figs. 3 and 4).

2. Recurrence was defined as the appearance of abdominal hydatidosis at any location, after one year of surgery.

Statistics: An exploratory data analysis was performed. Subsequently, descriptive statistics were used to calculate percentages, averages and standard deviations, medians and extreme values. Finally, incidence or absolute risk for the development of POM, reoperation, and recurrence was calculated.

Ethical principles: Written informed consent was obtained from each patient. All the ethical guidelines for research on human beings as defined by the Helsinki Declaration (Helsinki Statement of the World Wide Medical Association, 2000) were observed.

Funding: This study was partially financed by project DIDUFRO DI16-0119.

\section{RESULTS}

A total of 136 patients operated on for NLHC were recruited in this period, with no loss of follow-up (Fig. 5). Thirty-eight patients $(27.9 \%)$ had comorbidities among which stand out the cholelithiasis (21 cases, 15.4 $\%$ ) (Table II).

Table II. Concomitant comorbidity of the patients in study (N $=136$ ).

\begin{tabular}{lll}
\hline Variable & $\mathbf{N}^{\circ}$ cases & $\mathbf{\%}$ \\
\hline Concomitant pathology $(\%)$ & & \\
No diseases & 98 & 72.1 \\
Cholelithiasis & 21 & 15.4 \\
Chronic airflow limitation & 5 & 3.7 \\
Heart failure & 5 & 3.7 \\
Hepatic cirrhosis & 3 & 2.3 \\
Heart failure + Diabetes mellitus & 1 & 0.7 \\
Chronic renal failure & 1 & 0.7 \\
Pregnancy $(*)$ & 1 & 0.7 \\
Abdominal trauma $(* *)$ & 1 & 0.7 \\
\hline
\end{tabular}

(*): 15 weeks pregnancy

(**): Hepatic hydatidosis was an intraoperative finding during exploratory laparotomy due to abdominal trauma and was treated at the same surgical time.

The patients comprising the cohort are characterized by a median age of 41 years ( 15 a 84 años), $60.3 \%$ female and $30.9 \%$ of them having two or more cysts with a mean diameter of $14.9 \pm 5.9 \mathrm{~cm}$ (Table III).

Laboratory tests revealed median normal values (Table III), and regarding the qualitative measurements of specific immunoglobulin, IgG-ELISA and ELISA-IgE was positive in $69.9 \%$ and $55.1 \%$ of cases respectively.

The 136 subjects in the study had a total of 204 cysts of different size and location. Cysts were preferentially located in the right lobe $(63.2 \%)$ and were hypoechoic in $61.0 \%$ of the cases (Table IV).

The median surgical time was $95 \mathrm{~min}$. And the most frequently used surgical procedure was total or subtotal pericystectomy $(86.8 \%)$. Eighty-one of major cysts (59.6 $\%$ ), had biliary communications ( $25.0 \%$ had two or more). On the other hand, in $75.0 \%$ of the cases, another surgical procedure was performed concomitantly (Table IV).

The incidence or absolute risk of POM was $9.6 \%$ (13 patients throughout the follow-up period). Eleven patients $(8.1 \%)$, developed early POM and two (1.5\%), late complications. When applying the classification of Dindo \& Clavien, it was verified that in $92.3 \%$ of the patients in whom MPO was registered, this was Grade I or II. The etiology was ungrouped as follows: 8 cases $(5.9 \%)$, of complications of medical treatment (5 cases of atelectasis, 2 of acute postoperative bronchitis and one case of urinary tract infection); and 5 cases (3.7\%), of complications of 
Table III. Distribution of continuous variables of patients in study $(\mathrm{N}=136)$.

\begin{tabular}{llcc}
\hline Variable & Median & Extreme values & Average \pm SD \\
\hline Age (years) & 41.0 & $15-84$ & $43.3 \pm 17,2$ \\
Hematocrit (\%) & 39.0 & $30-54$ & $39.1 \pm 4.0$ \\
Leukocytes (x mm3) & 7650.0 & $3400-15400$ & $7919.4 \pm 2583.7$ \\
Total bilirubin (mg\%) & 0.6 & $0,1-2,7$ & $0.8 \pm 0.1$ \\
Alkaline phosphatases (U/1) & 291.5 & $60-3450$ & $418.1 \pm 408.1$ \\
Aspartate aminotransferase (U/1) & 24.0 & $10-407$ & $38.0 \pm 45.8$ \\
Alanine aminotransferase (U/l) & 24.5 & $8-436$ & $40.0 \pm 56.3$ \\
Cyst diameter (cm.) & 15.0 & $7-30$ & $14.9 \pm 5.9$ \\
Hospital stay (days) & 4.0 & $2-27$ & $5.1 \pm 2.9$ \\
Follow-up (months) & 115.0 & $12-190$ & $102.6 \pm 45.2$ \\
\hline
\end{tabular}

SD: $\quad$ Standard deviation

Table IV. Distribution of Categorical Variables of Patients in Study ( $\mathrm{N}=$ 136)

\begin{tabular}{|c|c|c|}
\hline Variable & $\mathbf{N}^{\circ}$ casEs & $\%$ \\
\hline \multicolumn{3}{|l|}{ Ultrasonographic Characteristics of Cysts $\left(^{*}\right)$} \\
\hline Hypoechoic & 83 & 61.1 \\
\hline Heterogeneous & 49 & 36.0 \\
\hline Hyperechoic & 4 & 2.9 \\
\hline \multicolumn{3}{|l|}{ Location of the cyst $(*)$} \\
\hline Right lobe & 86 & 63.2 \\
\hline Left lobe & 28 & 20.6 \\
\hline Bilateral & 22 & 16.2 \\
\hline \multicolumn{3}{|l|}{ Number of cysts } \\
\hline One & 94 & 69.1 \\
\hline Two & 31 & 22.8 \\
\hline Three or more & 11 & 8.1 \\
\hline \multicolumn{3}{|l|}{ Biliary communications $(*)$} \\
\hline None & 55 & 40.4 \\
\hline One & 47 & 34.6 \\
\hline Two or more & 34 & 25.0 \\
\hline \multicolumn{3}{|l|}{ S urgery perform ed $(*)$} \\
\hline Total or partial pericystectomy & 118 & 86.8 \\
\hline Liver resection & 18 & 13.2 \\
\hline \multicolumn{3}{|l|}{ Additional Surgical Procedures } \\
\hline None & 34 & 25.0 \\
\hline Cholecystectomy & 80 & 58.8 \\
\hline Cholecystectomy and choledochostomy & 20 & 14.7 \\
\hline Choledochostomy & 2 & 1.5 \\
\hline
\end{tabular}

(*): It refers to the main lesion in those patients who had two or more cysts surgical treatment (3 cases of infection of the superficial operative site, 1 case of residual cavity and 1 case of eventration [the latter two required a surgical reoperation, representing an incidence of reoperation of $1.47 \%$ in the followup period]) (Table V).

The median of hospital stay was 4 days (2 a 27 days).

No mortality was registered in the cohort.

With a median follow-up of 115 months respectively (12 to 190 months), one case of recurrence was verified, which represented an incidence of $0.7 \%$ for the period. This case was diagnosed three years after the primary surgery, and was operated 5 months after the diagnosis was made.
Table V. Morbidity of study patients $(\mathrm{N}=136)$.

\begin{tabular}{lll}
\hline Variable & $\mathbf{N}^{\circ}$ cases & $\mathbf{\%}$ \\
\hline Dindo \& Clavien & & \\
Grade 0 & 123 & 90.4 \\
Grade I & 9 & 6.7 \\
Grade II & 3 & 2.2 \\
Grade III & 0 & 0.0 \\
Grade IV & 1 & 0.7 \\
Grade V & 0 & 0.0 \\
Morbidity & & \\
None & 123 & 90.4 \\
Respiratory & 7 & 5.3 \\
Surgical site infection & 3 & 2.2 \\
Urinary tract infection & 1 & 0.7 \\
Residual cavity & 1 & 0.7 \\
Incisional hernia & 1 & 0.7 \\
\hline
\end{tabular}




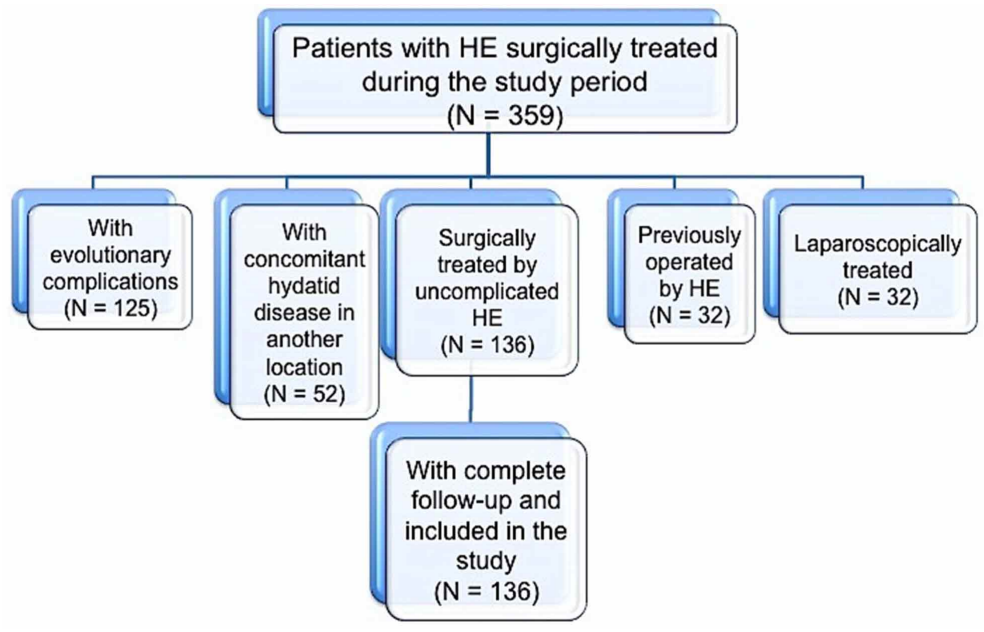

Fig. 5. Flow-chart of participants.

\section{DISCUSSION}

There are a small amount of reports regarding the study of early and late outcomes of surgery for NLHC, and most are retrospective case series, contributing evidence level 4 . This is how when performing a bibliographic search in PubMed database using the search strategy "Echinococcosis, Hepatic/surgery"[Mesh] OR "Liver hydatid cyst", a total of 2263 records were obtained which when debugged through the application of the Boolean operator NOT ("alveolar echinococcosis", "pulmonary echinococcosis", "lung echinococcosis", spleen, complicated, "pharmacological treatment", "laparoscopic surgery", PAIR, percutaneous, endoscopic), and some limits (articles published since 2005 to the date of the review [03/31/2017], in human and adult population), generated an amount of 217 articles. However, when we added limits related to the type of design of the articles seeking the best level of evidence (systematic reviews with or without meta-analysis, clinical trials with random assignment), the search generated only a total of 6 articles. This means that, in the period of this search, more than $95 \%$ of the articles referring to HE surgery are series of cases, most of which contain heterogeneous populations and, therefore with results whose internal validity is objectionable.

Notwithstanding all of the above, it is outstanding that in spite of the technological advance, POM of HE persists high (rates from $21.3 \%$ to $53.8 \%$ ) (Yorganci et al.; Nari et al.; Atmatzidis et al.; Daradkeh et al.; Gourgiotis et al., 2007; Agayev \& Agayev), especially because is considered to be a benign disease.
We believe that the reported POM $(9.6 \%)$ is relevant, however certain clinical characteristics of these patients, such as their concomitant comorbidities (in $16.2 \%$ of patients triggered the need for concomitant surgeries), number and diameter of cysts, presence of biliary communication ( $59.6 \%$ of cases), etc. variables associated with increased POM (Manterola et al., 2005; Manterola et al., 2010; Bedioui et al., 2012; Manterola et al., 2014; Baraket et al., 2014). This POM rate is among previously published ranks (10.8\% to $24.3 \%$ ) (Ozacmak et al., 2000; Atmatzidis et al.; Reza Mousavi et al., 2005; Gourgiotis, 2007; Agayev \& Agayev; Yüksel, 2008; Manterola et al., 2013; Mosaddeghi et al., 2014; Manterola et al., 2014), to which must be added that the severity of complications is mostly low, and only $38.5 \%$ of the cases were of surgical treatment with a lower incidence of re-interventions than reported (Bektas et al., 2001). On the other hand, the reported morbidity was analyzed over an extended followup period (115 months), which far exceeds previous reports.

The median length of hospital stay of 4 days is less than previously published data ranging from 6.5 to 23 days (Franciosi et al., 2002; Nari et al.; Hofstetter et al., 2004; Atmatzidis et al.; Reza Mousavi et al.; Prousalidis et al., 2009).

Moreover, the incidence of recurrence $(0.7 \%$ in the study period), also contrasts with previous numbers ranging between $1.5 \%$ and $7.3 \%$ (Nari et al.; Hofstetter et al.; Kapan et al., 2006; Gourgiotis et al., 2007; Prousalidis et al.), to which the long follow-up period has been added. 
Finally, the absence of mortality of this cohort stands out when comparing it with different series, in which rates between $0.3 \%$ and $3.7 \%$ have been reported (Franciosi et al., 2002; Nari et al.; Cooney et al., 2004; Atmatzidis et al.; Kapan et al.; Gourgiotis et al., 2007; Daradkeh et al.; Agayev \& Agayev; Prousalidis).

The novelty of this proposal is related to: the design used, which despite being a heterogeneous population, are patients with uncomplicated hepatic hydatidosis and with an extensive follow-up period (minimum 12 months). This makes it possible to verify the late POM that is not usually reported in most publications.
However, we are aware that the study presents some potential sources of bias that merit comment. One of these has to do with the heterogeneity of the population. Another is related to the sample size, because there are no more cases to report. However, complete follow-up of the cohort and extended follow-up time are tools that enhance data quality.

By way of conclusion, we can note that POM was determined in a cohort of patients with NLHC throughout an extended follow-up period, and the incidence and gravity of POM is smaller and of lower gravity than those previously published.

MANTEROLA, C.; OTZEN, T. \& MINCIR group. Resultados precoces y tardíos de la cirugía de la hidatidosis hepática no complicada. Int. J. Morphol., 35(2):556-563, 2017.

RESUMEN: Siendo una equinococosis hepática (EH) un problema de salud prevalente, la información publicada respecto a la cirugía de EH no es abundante. Por otro lado, la morbilidad postoperatoria (MPO) no ha variado de forma muy significativa. El objetivo de este estudio fue describir los resultados tempranos y tardíos en términos de MPO de una serie de pacientes con quistes hidatídicos hepáticos no complicados (QHHN) tratados quirúrgicamente. Estudio de cohorte prospectiva. Se incluyeron pacientes sometidos a cirugía para QHHN en el Hospital Regional y Clínica en Temuco, entre 2000 y 2015. La variable resultado principal fue desarrollo de MPO temprana y tardía. Otras variables de interés fueron estancia hospitalaria, mortalidad y recurrencia. Las técnicas quirúrgicas utilizadas fueron periquistectomía total o subtotal y resección hepática. Se calcularon porcentajes, medidas de tendencia central y dispersión, e incidencia. Se estudiaron 136 pacientes con una mediana de edad de 41 años; 60,3\% de los cuales son mujeres. La mediana del diámetro de los quistes y del tiempo quirúrgico fue de $15,0 \mathrm{~cm}$ y $95 \mathrm{~min}$. Respectivamente. La incidencia de MPO fue $9,6 \%$, de los cuales 92,3\% fueron Grado I o II de Dindo y Clavien. La etiología fue: 5,9 \% de complicaciones médicas y 3,7 \% de complicaciones quirúrgicas. No hubo mortalidad; y con una mediana de seguimiento de 115 meses, se determinó una incidencia de recidiva de $0,7 \%$ (1 paciente, en el período estudiado). Se describe la MPO de una cohorte de pacientes con QHHN. La morbilidad observada es inferior a la publicada y de bajo nivel de gravedad.

PALABRAS CLAVE: Hidatidosis hepática; Quiste hidatídico hepático; Resultados de tratamientos; Complicaciones postoperatorias.

\section{REFERENCES}

Agayev, R. M. \& Agayev, B. A. Hepatic hydatid disease: surgical experience over 15 years. Hepatogastroenterology, 55(85):1373-9, 2008

Apablaza, P. S.; Burmeister, L. R.; Benavides, C. C.; Gacitua, G. H. \& Nara, D. F. Tratamiento del quiste hidatídico hepático. Rev. Chil. Cir., 44(4):424-7, 1992.

Atmatzidis, K. S.; Pavlidis, T. E.; Papaziogas, B. T.; Mirelis, C. \& Papaziogas, T. B. Recurrence and long-term outcome after open cystectomy with omentoplasty for hepatic hydatid disease in an endemic area. Acta Chir. Belg., 105(2):198-202, 2005.

Baraket, O.; Moussa, M.; Ayed, K.; Kort, B. \& Bouchoucha, S. Predictive factors of morbidity after surgical treatment of hydatid cyst of the liver. Arab. J. Gastroenterol., 15(3-4):119-22, 2014.

Bedioui, H.; Bouslama, K.; Maghrebi, H.; Farah, J.; Ayari, H.; Hsairi, H.; Kacem, M.; Jouini, M. \& BenSafta, Z. Predictive factors of morbidity after surgical treatment of hepatic hydatid cyst. Pan. Afr. Med. J., 13:29, 2012.

Bektas, H.; Lehner, F.; Werner, U.; Bartels, M.; Piso, P.; Tusch, G.; Schrem, H. \& Klempnauer, J. Surgical therapy of cystic echinococcosis of the liver. Zentralbl. Chir., 126(5):369-73, 2001.
Camacho, J.; Reyes, J.; Pérez, A.; Arancibia, H. Buckel, E. \& Giordano, J. Cirugía del quiste hidatídico hepático. Rev. Chil. Cir., 48(5):479-82, 1996.

Clavien, P. A.; Barkun, J.; de Oliveira, M. L.; Vauthey, J. N.; Dindo, D.; Schulick, R. D.; de Santibañes, E.; Pekolj, J.; Slankamenac, K.; Bassi, C.; Graf, R.; Vonlanthen, R.; Padbury, R.; Cameron, J. L. \& Makuuchi, M. The Clavien-Dindo classification of surgical complications: fiveyear experience. Ann. Surg., 250(2):187-96, 2009.

Cooney, R. M.; Flanagan, K. P. \& Zehyle, E. Review of surgical management of cystic hydatid disease in a resource limited setting: Turkana, Kenya. Eur. J. Gastroenterol. Hepatol., 16(11):1233-6, 2004.

Correa, T. S.; Culqui, L. C.; Pinto, P. M.; Huillca, L. \& Salinas, A. E. Hidatidosis hepática: revisión de casos intervenidos quirúrgicamente en el Hospital Militar Central Lima 1990-1999. Rev. Gastroenterol. Perú, 20(3):261-9, 2000

Daradkeh, S.; El-Muhtaseb, H.; Farah, G.; Sroujieh, A. S. \& Abu-Khalaf, M. Predictors of morbidity and mortality in the surgical management of hydatid cyst of the liver. Langenbecks Arch. Surg., 392(1):35-9, 2007.

Dindo, D.; Demartines, N. \& Clavien, P. A. Classification of surgical complications: a new proposal with evaluation in a cohort of 6336 patients and results of a survey. Ann Surg., 240(2):205-13, 2004. 
Dziri, C.; Haouet, K. \& Fingerhut, A. Treatment of hydatid cyst of the liver: where is the evidence? World J. Surg., 28(8):731-6, 2004.

Franciosi, C. M.; Romano, F.; Porta, G.; Caprotti, R.; De Fina, S.; Colombo, G.; Porta, A. \& Uggeri, F. Surgical treatment of hydatid disease of the liver. An experience from outside the endemic area. Chir. Ital., 54(5):66772, 2002.

González, G. D. A.; Vega, L. A.; Monti, A. J. D. \& Torres, A. M. O. Enfermedad hidática hepática: experiencia de los últimos 13 años en Florida. Cir. Urug., 69(3-4):200-3, 1999.

Gourgiotis, S.; Stratopoulos, C.; Moustafellos, P.; Dimopoulos, N.; Papaxoinis, G.; Vougas, V. \& Hadjiyannakis, E. Surgical techniques and treatment for hepatic hydatid cysts. Surg. Today, 37(5):389-95, 2007.

Helsinki Statement of the World Wide Medical Association. Ethical principles for the medical researches in human beings. Amended by 52nd General Assembly, Edinburgh, Scotland, 2000.

Hermosilla, S. P.; Cruzat, A.; Venturelli, L. A.; Kuschel, H. C.; Murúa, B. A. \& Díaz, B. J. Hidatidosis hepática. Análisis de 81 casos operados. Rev. Chil. Cir., 43(1):47-50, 1991.

Hofstetter, C.; Segovia, E. \& Vara-Thorbeck, R. Treatment of uncomplicated hydatid cyst of the liver by closed marsupialization and fibrin glue obliteration. World J. Surg., 28(2):173-8. 2004.

Kapan, M.; Kapan, S.; Goksoy, E.; Perek, S. \& Kol, E. Postoperative recurrence in hepatic hydatid disease. J. Gastrointest. Surg., 10(5):7349, 2006.

Manterola, C. \& Otzen, T. Checklist for reporting results using observational descriptive studies as research designs. The MInCir initiative. Int. J. Morphol., 35(1):72-6, 2017a.

Manterola, C. \& Otzen, T. Cholangiohydatidosis: An infrequent cause of obstructive jaundice and acute cholangitis. Ann. Hepatol., 16(2), $2017 \mathrm{~b}$. In press.

Manterola, C. \& Otzen, T. Hepatic echinococcosis with thoracic involvement. Clinical characteristics of a prospective series of cases. Ann. Hepatol., 16(3), 2017c. In press.

Manterola, C.; Barroso, M.; Vial, M.; Bustos, L.; Muñoz, S.; Losada, H.; Bello, N.; Hernández, F. \& Carrasco, R. Liver abscess of hydatid origin: clinical features and results of aggressive treatment. A. N. Z. J. Surg., 73(4):220-4, 2003b.

Manterola, C.; Losada, H.; Carrasco, R,: Muñoz, S.; Bustos, L.; Vial, M. \& Innoccenti, G. Cholangiohydatidosis. An evolutive complication of hepatic hydatidosis. Bol. Chil. Parasitol., 56(1-2):10-5, 2001.

Manterola, C.; Otzen, T.; Urrutia, S. \& MINCIR Group (Methodology and Research in Surgery). Risk factors of postoperative morbidity in patients with uncomplicated liver hydatid cyst. Int. J. Surg., 12(7):695-9, 2014.

Manterola, C.; Roa, J. C.; Urrutia, S. \& MINCIR Group. Treatment of the residual cavity during hepatic hydatidosis surgery: a cohort study of capitonnage vs. omentoplasty. Surg. Today, 43(12):1412-8, 2013.

Manterola, C.; Urrutia, S. \& Grupo MINCIR. Post surgery morbidity in patients with complicated hepatic hydatidosis. Rev. Chil. Infectol., 32(1):43-9, 2015a.

Manterola, C.; Urrutia, S. \& MINCIR GROUP. Infected hepatic echinococcosis: Results of surgical treatment of a consecutive series of patients. Surg. Infect. (Larchmt.)., 16(5):553-7, $2015 \mathrm{~b}$.

Manterola, C.; Vial, M.; Losada, H.; Fonseca, F.; Bustos, L.; Muñoz, S. \& Barroso, M. Uncommon locations of abdominal hydatid disease. Trop. Doct., 33(3):179-80, 2003a.

Manterola, C.; Vial, M.; Pineda, V.; Sanhueza, A. \& Barroso M. Factors associated with morbidity in liver hydatid surgery. A. N. Z. J. Surg., 75(10):889-92, 2005.

Manterola, C.; Vial, M.; Sanhueza, A. \& Contreras, J. Intrabiliary rupture of hepatic echinococcosis, a risk factor for developing postoperative morbidity: a cohort study. World J. Surg., 34(3):581-6, 2010.

Manterola, C.; Vial, M.; Schneeberger, P.; Peña, J. L.; Hinostroza, J. \& Sanhueza, A. Precision of ELISA-IgE and ELISA-IgG determination in the postoperative follow-up of patients with hepatic echinococcosis. Cir. Esp., 81(1):23-7, 2007.

Manterola, D. C.; Ávila, A. N.; Seco, V. J.; Ulloa, M. P.; Moraga, C. J. \&
Grupo MInCir. Hepatothoracic transit, evolutionary complications of hepatic echinoccocosis. Rev. Chil. Cir., 61(4):345-9, 2009b.

Manterola, D. C.; Sanhueza, C. A.; Vial, G. M.; Moraga, C. J. \& Grupo MInCir. Liver abscess of hydatid origin as a risk factor for postoperative complications in hydatidosis. Rev. Chil. Cir., 61(4):333-8, 2009a.

Martínez, G. P. Human hydatidosis disease: general background and epidemiological situation in Chile, 2001-2009. Rev. Chil. Infectol., 28(6):585-91, 2011.

Mosaddeghi, K. S.; Heris, H. K.; Bayat, A. \& Mosaddeghi, K. Z. Capsulorrhaphy in the management of liver hydatid cyst. Ann. Hepatol., 13(3):378-83, 2014.

Nari, G.; Ponce, O.; Cirami, M.; Jozami, J.; Toblli, J.; Eduardo, M. \& Fernando, M. Five years experience in surgical treatment of liver hydatidosis. Int. Surg., 88(4):194-8, 2003.

Ozacmak, I. D.; Ekiz, F.; Ozmen, V. \& Isik, A. Management of residual cavity after partial cystectomy for hepatic hydatidosis: comparison of omentoplasty with external drainage. Eur. J. Surg., 166(9):696-9, 2000.

Pinto, G. P. P. Hidatidosis hepática: estudio de una serie de 534 casos. Rev. Chil. Cir., 43(2):184-7, 1991.

Prousalidis, J.; Kosmidis, C.; Kapoutzis, K.; Fachantidis, E.; Harlaftis, N. $\&$ Aletras. H. Intrabiliary rupture of hydatid cysts of the liver. Am. J. Surg., 197(2):193-8, 2009.

Reza Mousavi, S.; Khoshnevis, J. \& Kharazm, P. Surgical treatment of hydatid cyst of the liver: drainage versus omentoplasty. Ann. Hepatol., 4(4):272-4, 2005.

Sapunar, Z. J.; Rappoport, S. J.; Sapunar, P. J. \& Cumsille, F. Quiste hidatídico hepático: características clínicas, factores pronósticos y resultados quirúrgicos. Parasitol. Día, 13(2):52-63, 1989.

Sarotto, L.; Nallar, M.; Ferraro, A.; Danguise, E.; Merello, J. \& Ferraina, P. Tratamiento quirúrgico de la hidatidosis hepática: experiencia en el Hospital de Clínicas en los últimos 15 años. Rev. Argent. Cir., 76(3-4):94$105,1999$.

Yorganci, K.; \& Sayek, I. Surgical treatment of hydatid cysts of the liver in the era of percutaneous treatment. Am. J. Surg., 184(1):63-9, 2002.

Yüksel, O.; Akyürek, N.; Sahin, T.; Salman, B.; Azili, C. \& Bostanci, H. Efficacy of radical surgery in preventing early local recurrence and cavity-related complications in hydatic liver disease. J. Gastrointest. Surg., 12(3):483-9, 2008.

\section{Corresponding author: \\ Dr. Carlos Manterola}

Department of Surgery and CEMyQ

Universidad de La Frontera.

Manuel Montt 112, office 408

Temuco

CHILE

\section{E-mail: carlos.manterola@ufrontera.cl}

Received: $16-10-2016$

Accepted: 26-12-2016 